\title{
Does foreign bank entry make Chinese banks stronger?
}

\begin{abstract}
:
China has encouraged its domestic banks to introduce foreign investment since the early 2000s. In the meantime, China has gradually fulfilled its WTO accession commitment to give foreign banks the same treatment as their Chinese counterparts in the last decade. This research has examined the effects of the two modes of foreign bank entry, namely, minority ownership participation, and setting up branches and subsidiaries, on the performance of Chinese banks. Our results suggest that there is no systematically significant impact of the minority ownership participation on the performance indicators of Chinese banks. However, it appears that the physical presence of foreign banks has been a significant driver for domestic banks to improve profitability and efficiency. Opening the country to foreign banks appears to have made Chinese banks stronger and more competitive.
\end{abstract}

\section{Keywords:}

Chinese banks, foreign bank entry, minority ownership, bank performance

\section{JEL codes:}

G21, G28, G34 


\section{Introduction}

Foreign bank entry modes include establishing a wholly foreign-owned bank, opening a branch or representative office, entering into a joint venture with a local partner and acquiring an equity share in an existing bank (Hope et al., 2008). In China, the first three modes lead to the banks being regarded as foreign banks that are subject to the rules and regulations governing foreign banks. Xu (2011) and Lin (2011) have noted that establishing a bank branch was the main form of foreign bank presence in China. By the end of 2011, 37 foreign-owned banks had been set up and were operating with 245 branches. In addition, 77 foreign banks and two joint venture banks had opened 94 and 10 branches, respectively. However, foreign strategic investment in Chinese banks as another form of foreign entry has become increasingly important in the last decade. Before 2003, only a small number of Chinese banks were allowed to bring in foreign capital. However, a flood of foreign investment by overseas financial institutions flowed into China's domestic banks after the Administrative Rules Governing the Equity Investment in Chinese Financial Institutions by Overseas Financial Institutions was promulgated in $2003 .^{1}$

China's banking reforms and development have received much attention in the literature (see, for example, Berger et al., 2009; Lin \& Zhang, 2009; Xu, 2011). Lin and Zhang (2009) examined the effect of ownership on the performance of China's banking industry for the period 1997-2004, while Xu (2011) looked at the impact of the presence of foreign banks on China's banking performance for the 1999-2006 period. However,

\footnotetext{
${ }^{1}$ Currently, China has set upper limits for foreign ownership in domestic banks: 25 per cent for total foreign ownership and 20 per cent for a single foreign investor. Exceeding the 25 per cent limit will result in the bank being treated as a foreign bank. This rule does not apply to publicly listed banks and they will be regarded as domestic banks even if foreigners hold more than 25 per cent equity. So far none of the domestic banks have changed their Chinse identity as a result of the ownership acquisition.
} 
it appears that most of the previous studies only concentrate on one type of foreign bank entry without controlling for the potential impact of other entry modes, which could cause omitted-variable bias. This study will simultaneously consider two main forms of foreign bank entry, namely, directly setting up branches and subsidiaries, and taking on minority ownership, and see if they have weakened or improved the performance of Chinese banks. Following previous literature, the performance indicators included in this study are return on assets (ROA), return on equity (ROE), Tier 1 capital ratio (TCR1), total capital ratio (TCR), and the cost to income ratio (COI).

It is worth noting that most of the strategic partnerships between Chinese and foreign banks were established between 2004 and 2006 as shown in Table 1. Most of the existing studies only cover a period before or shortly after the 2004-06 acquisition wave, which is not long enough to reveal the full impact of the strategic partnership that took place in the 2000s. It is, therefore, necessary to re-examine the effects of both foreign equity participation and the physical presence of foreign banks using data from a period (2002-11) long enough to reveal the short run and long run effects. Both static and dynamic panel data models are employed in this study. The dynamic panel data model can be used to address the potential endogeneity problem associated with foreign bank entry which has been largely ignored in previous literature such as Lin and Zhang (2009).

The next section summarises the potential benefits and costs of foreign bank entry. Section 3 presents the findings of previous research that are most relevant to this study. Section 4 defines the dependent and independent variables and provides the data sources. 
Section 5 interprets the econometric results and compares our findings with those of previous studies. The last section articulates the policy implications.

\section{Potential benefits and costs of foreign bank entry}

Chen et al. (2009) summarise the potential benefits of introducing foreign capital to Chinese banks: improving the corporate management structure, bringing in new technologies, products and management skills, and increasing capital adequacy ratios. The uniform state-owned equity structure of the SCBs implies that the firms may have to serve social goals in addition to commercial performance. Martin and Parker (1997) contend that when state-owned firms pursue other objectives, the ability to achieve efficiencies is weakened. It is, therefore, not surprising that the SCBs had long been characterised with an overly high percentage of bad assets and low competitiveness (Chen et al., 2009). At the end of 2003 only eight commercial banks reached the minimum capital adequacy ratio of 8 per cent, but all of the banks met this requirement in 2011. Another benefit of introducing foreign strategic investment is that minority foreign investment may serve as a quality signal to the capital market, thereby increasing the revenue per share in the IPO market (Berger et al., 2009). After introducing foreign strategic partners, three of the SCBs launched very successful IPOs in both Hong Kong and Shanghai stock markets. It is also believed that a foreign strategic partner has a positive effect on a bank's prudent behaviour and can help improve the accuracy and transparency of domestic banks' financial records, thereby increasing global investor confidence and opening new business opportunities for Chinese banks. This has been evident by the speed of their network expansion around the world in the recent years. By the end of 2011 the Big Four and the Bank of 
Communications had set up 105 overseas branches and had invested in 10 foreign companies. $^{2}$

However, there are potential problems associated with the influx of foreign capital. For example, foreign financial institutions tend to undervalue the value of Chinese banks and want to bargain a low acquisition price, sometimes even much lower than the market price. In addition, the introduction of foreign equity may increase the possibility of contagion and susceptibility to any financial crisis (Chen et al., 2009). On the last day of 2008, just one day after the expiry of the lock-up period during which foreign investors were not allowed to sell their stakes in Chinese companies, Swiss bank UBS AG sold its entire 1.3 per cent stake in the Bank of China for US\$808 million. On 13 January 2009 the Royal Bank of Scotland sold its 4.26 per cent equity stake in the Bank of China for US\$2.3 billion to shore up its own balance sheet. Also in January 2009 the Bank of America announced that it would sell 5.6 billion of its shares in the Construction Bank of China, thereby reducing its stake in this bank from 19.13 per cent to 16.6 per cent. The exodus of foreign investors during the $2008-09$ global financial crisis led to a drop of the share price of these banks and posed a risk to China's financial system.

Although the number of branches of foreign banks in China has almost doubled since the relaxation of foreign bank entry in the early 2000s under the WTO commitments, foreign banking assets remain a small percentage of China's total banking assets: the 1.93 per cent in 2011 was only a slight rise from the 1.84 per cent in 2004 . Nevertheless,

\footnotetext{
${ }^{2}$ The "Big Four" refers to the four largest banks by market share within China: the Bank of China (BOC), the China Construction Bank (CCB), the Industrial and Commercial Bank of China (ICBC) and the Agricultural Bank of China (ABC).
} 
$\mathrm{Xu}(2011)$ notes that foreign banks are experienced in trade finance and foreign exchange business, which enables them to provide sophisticated banking services to their Chinese clients. This will pose a competitive threat to the domestic banks and force them to be innovative and to improve customer services. Even though most of the foreign banks are concentrated in a few capital cities, apart from head-to-head competition in those cities, they also pose a threat to their Chinese counterparts whose pricing and lending behaviour in other parts of China will be constrained by the potential entry of foreign banks there. In response to this, Chinse banks have already taken action to deal with the problems of non-performing loans and low capital adequacy and have begun to restructure their internal organisation and decision-making processes (He \& Fan, 2004).

The relatively low market share commanded by foreign banks at this stage implies that domestic banks have not been under any serious threat. However, concerns remain. He and Fan (2004) warn that in the face of competition from foreign banks, the response by Chinese banks may widen the development gap between regions, as the banks may shift away from less developed areas and increasingly focus on market niches that are regarded as more lucrative, which means that some areas will be under-serviced. Foreign banks are unlikely to step in to this banking service vacuum as they tend to "cherry pick" the most profitable domestic markets and customers, which will increase the overall riskiness of the domestic banks' portfolios (Mathieson \& Roldos, 2001). In addition, due to the close link between foreign banks and their parent banks, funding shocks to the parent banks can be transmitted to their subsidiaries in China, especially during the period of financial crisis. This may lead to a reduction in lending, posing a 
risk to the stability of the financial system. De Haas and van Lelyveld (2010) report that lending by multinational bank subsidiaries in European transition economies is sensitive to profitability changes in other subsidiaries of the parent bank. During the global financial crisis, foreign subsidiaries reduced their lending earlier and faster than did domestic banks (De Haas et al., 2011).

\section{Related studies on the effects of foreign bank entry on domestic banks}

Berger et al. (2009) analyse the profit and cost efficiency of 38 Chinese banks over 1994-2003. They find that the Big Four banks were the least efficient and that minority foreign ownership was associated with significantly improved efficiency, implying that the reduction in state ownership of banks in China was the right reform. Using a panel of Chinese banks over the 1997-2004 period, Lin and Zhang (2009) find that state ownership is negatively related to bank performance with the Big Four banks having the worst accounting ratios, thus providing some support for ongoing bank ownership reform in China. Hasan and Xie (2012) acknowledge that at this stage the ownership shares of foreign strategic investors are relatively small and their management involvement is minimal. However, their findings suggest that foreign minority investment exerts a positive effect on banks' prudent behaviour through an improved corporate governance system. In their event study analysis, a positive market reaction to foreign strategic investment announcements was observed. It also appears that, due to limited ownership involvement, foreign banks had less of a contagion effect on Chinese banks during the global financial crisis. 
However, Jiang et al. (2012) find no evidence that foreign minority ownership in domestic banks improved performance over the 1995-2008 period. One possible reason is that after foreign owners take minority ownership, it is the domestic banks that undertake most of the investing activities such as upgrading technology and applying prudential practices such as more loan loss provision. This will undoubtedly sacrifice profitability in the short term but may benefit the banks in the long term. In addition, it takes time for the domestic banks to adapt to the managerial and operational skills brought about by the new strategic partners. Shen et al. (2009) present similar findings, that is, foreign bank penetration measured by the percentage of foreign investment affects neither profitability nor costs. The authors argue that after allowing foreign investors to participate in Chinese banks, the local banks might invest in training staff to enhance their human capital or increase their investment in computer programs and equipment to use cutting-edge technologies, both of which result in increased costs and revenues. Cultural differences and different strategic goals as well as the lack of employees who are fluent in English and who are familiar with international affairs might create additional obstacles that have a negative impact on the cooperation between Chinese banks and their foreign investors. Other countries have had similar experiences. By examining the impact of changes in bank governance on bank performance for a sample of commercial banks operating in South East Asia between 1990 and 2003, Williams and Nguyen (2005) admit that there is not a clear conclusion concerning foreign acquisition - although banks taken over by foreign institutions have improved profit efficiency performance, their productivity performance is not amongst the strongest. The authors agree that the benefits of foreign governance will take a long time to be realised. 
Regarding the presence of foreign banks in domestic markets, Denizer (2000) finds that foreign banks have the effect of reducing overhead expenses and the return on assets of the domestic banks in Turkey, indicating that even if small in scale, foreign bank entry tends to put competitive pressure on the domestic banks. In a comprehensive study covering 80 countries, Claessens et al. (2001) claim that the increased presence of foreign banks is associated with a reduction in profitability and margins for domestic banks. Lensink and Hermes (2003) find that at lower levels of economic development, foreign bank entry is related to increasing costs and margins for domestic banks, while at higher levels of development costs, the relationship is less clear. Xu (2011) reveals that the presence of foreign banks in China has a positive relationship with the noninterest income, and a negative relationship with the net interest margins of domestic banks. In addition, an increased foreign bank presence is associated with an increase in costs for domestic banks.

It appears that the effect of foreign bank entry on the performance of domestic banks is not clear-cut. The use of various performance measures and control variables in different studies may also explain the variation in the findings. This research will contribute to the ongoing debate on this issue by examining the effects of foreign ownership participation in Chinese banks, and setting up braches and subsidiaries in China, respectively.

\section{Methodology and data}

\subsection{Measuring performance}


Following previous literature such as Lin and Zhang (2009), the performance variables used as dependent variables include ROA and ROE. However, Bonin et al. (2005) warn that measures of bank performance in transition countries are sensitive to the strategies used to write off bad loans. They are also easy to manipulate. Therefore, we also consider capital adequacy ratios, including TCR1 and TCR, which were a significant consideration when the banks sought strategic partners. TCR1 is defined as the ratio of a bank's core equity capital to its total risk-weighted assets. TCR is determined by dividing total capital by risk-weighted assets. Previous literature suggests that a high level of state ownership is associated with high operating cost and low efficiency (Bonin et al. 1998), while foreign bank entry tends to reduce overheads and to improve efficiency (Xu 2011). We thus include the cost to COI as a dependent variable to approximate bank efficiency and to see if the introduction of foreign ownership has improved cost efficiency.

\subsection{Measuring foreign bank entry}

We attempt to measure the foreign bank entry variable in several ways. We use both the percentage of foreign investment and dummy variables to account for the presence of foreign investors. However, it is understood that it may take time for the Chinese banks to improve their performance. Therefore, we include a dummy that takes the value of 1 immediately after the introduction of foreign partners and a dummy that takes the value of 1 three years after the foreign ownership participation. We call the two dummies "foreign ownership dummy" and "long run dummy", respectively, in the following sections. 
Setting up a foreign-owned bank or opening a branch is another form of entry to China for foreign banks. The presence of foreign banks in China is most likely to have promoted competition, forcing their domestic counterparts to cut costs and to provide better services. Therefore, we include the number of branches of foreign banks, including joint venture banks, in our models. This variable is denoted as foreign branches in the tables.

\subsection{Control variables}

We control for macroeconomic variables and bank specific characteristics. The macroeconomic variables include the annual GDP growth rate and the inflation rate. ${ }^{3}$

Individual banks, total assets in logarithmic form are used as an independent variable to represent the size of the bank. A dummy variable is included if a bank is publicly listed in the stock market (public listing dummy). Lin and Zhang (2009) claim that newly established banks are more profitable and more efficient than the SCBs. We thus include a dummy variable for the Big Four.

Following Berger et al. (2005) and Lin and Zhang (2009), we identify the banks that did not experience any change in ownership over the sample period and create a dummy variable (no ownership change dummy) for these banks taking the value of 1 for all time periods.

\subsection{The data}

\footnotetext{
${ }^{3}$ We have attempted to include more bank type dummies in the models such as the dummies denoting banks that operate at the national level with and without foreign investment participation. Unfortunately, none of them are statistically significant.
} 
Our sample consists of unbalanced annual data, including observations from 2002 to 2011 for 39 banks. Although we tried many different sources, the data for some periods were not available for some banks. The policy banks created by the government are not included as they are not-for-profit organisations. The sample includes 11 national level banks, including the Big Four, and 28 provincial and city-level banks. Thirteen of the 39 banks were without foreign ownership participation, including one of the Big Four (the Agricultural Bank of China). The 26 banks that have had foreign ownership participation are listed in Table 1. It should be acknowledged that most of the provincial and city-level banks have set up branches in major cities such as Beijing and Shanghai and their business is not just confined to their province or city. The data for these performance variables come from various sources which include Bankscope, China's Wind Information and the banks' annual financial reports. The macroeconomic variables such as GDP growth and inflation can be found in the China Statistical Database compiled by the National Bureau of Statistics of China.

\section{Table 1: Banks contained in the sample that have introduced overseas strategic} partners.

\begin{tabular}{|c|c|c|c|c|}
\hline & Chinese domestic banks & Acquisition time & Overseas investors & $\begin{array}{c}\text { Foreign } \\
\text { investment } \\
\text { percentage }\end{array}$ \\
\hline 1 & China Everbright Bank & 1996.1 & Asian Development Bank & $3.29 \%$ \\
\hline \multirow{3}{*}{2} & \multirow{3}{*}{ Bank of Shanghai } & 1999.12 & International Finance Corporation & $7.00 \%$ \\
\hline & & \multirow[b]{2}{*}{2001.12} & HSBC & $8.00 \%$ \\
\hline & & & $\begin{array}{c}\text { Shanghai Commercial Bank(Hong } \\
\text { Kong) }\end{array}$ & $3.00 \%$ \\
\hline \multirow{2}{*}{3} & \multirow{2}{*}{ Bank of Nanjing } & 2001.11 & International Finance Corporation & $15.00 \%$ \\
\hline & & 2005.12 & BNP Paribas & $19.20 \%$ \\
\hline 4 & $\begin{array}{c}\text { Shanghai Pudong Development } \\
\text { Bank }\end{array}$ & 2002.12 & Citibank & $4.62 \%$ \\
\hline 5 & Bank of Xi'an & 2002.9 & $\begin{array}{c}\text { International Finance Corporation、 } \\
\text { Scotiabank (Canada) }\end{array}$ & $24.90 \%$ \\
\hline 6 & Industrial Bank & 2003.12 & Hang Seng Bank (Hong Kong) & $15.98 \%$ \\
\hline
\end{tabular}




\begin{tabular}{|c|c|c|c|c|}
\hline & & & $\begin{array}{l}\text { Government of Singapore } \\
\text { Investment Corporation }\end{array}$ & $5.00 \%$ \\
\hline & & & International Finance Corporation & $4.00 \%$ \\
\hline 7 & Bank of Communications & 2004.8 & HSBC & $19.90 \%$ \\
\hline \multirow{2}{*}{8} & \multirow{2}{*}{ Qilu Bank } & 2004.11 & Commonwealth Bank of Australia & $11.00 \%$ \\
\hline & & 2009.6 & Commonwealth Bank of Australia & $9.00 \%$ \\
\hline \multirow{2}{*}{9} & \multirow{2}{*}{ China Mingsheng Banking } & 2003.9 & International Finance Corporation & $1.22 \%$ \\
\hline & & 2004.11 & Temasek Holdings (Singapore) & $4.55 \%$ \\
\hline 10 & Shenzhen Development Bank & 2004.12 & Newbridge Capital (USA) & $17.89 \%$ \\
\hline 11 & Hangzhou Commercial Bank & 2005.4 & Commonwealth Bank of Australia & $19.90 \%$ \\
\hline \multirow{2}{*}{12} & \multirow{2}{*}{ China Construction Bank } & 2005.6 & Bank of America & $9.10 \%$ \\
\hline & & 2005.7 & Temasek Holdings (Singapore) & $5.10 \%$ \\
\hline \multirow{4}{*}{13} & \multirow{4}{*}{ Bank of China } & 2005.12 & Royal Bank of Scotland & $10.00 \%$ \\
\hline & & 2005.8 & Temasek Holdings & $5.00 \%$ \\
\hline & & 2005.9 & United Bank of Switzerland AG & $1.61 \%$ \\
\hline & & 2005.1 & Asian Development Bank & $0.24 \%$ \\
\hline \multirow{2}{*}{14} & \multirow{2}{*}{ Bank of Beijing } & \multirow{2}{*}{2005.9} & ING (Netherlands) & $19.90 \%$ \\
\hline & & & International Finance Corporation & $5.00 \%$ \\
\hline 15 & Hua Xia Bank & 2005.9 & Deutsche Bank & $14.00 \%$ \\
\hline 16 & Bohai Bank & 2004.12 & $\begin{array}{c}\text { Standard Chartered Bank (Hong } \\
\text { Kong) }\end{array}$ & $19.99 \%$ \\
\hline 17 & $\begin{array}{c}\begin{array}{c}\text { Industrial and Commercial Bank } \\
\text { of China }\end{array} \\
\end{array}$ & 2005.8 & $\begin{array}{c}\text { Goldman Sachs, Allianz Group, } \\
\text { American Express } \\
\end{array}$ & $10.00 \%$ \\
\hline 18 & Tianjin Bank & 2005.12 & \begin{tabular}{|c|} 
Australia and New Zealand Banking \\
Group
\end{tabular} & $20.00 \%$ \\
\hline 19 & Bank of Ningbo & 2006.1 & Oversea-Chinese Bank (Singapore) & $12.20 \%$ \\
\hline 20 & China Guangfa Bank & 2006.11 & Citibank & $20.00 \%$ \\
\hline \multirow{2}{*}{21} & \multirow{2}{*}{ China CITIC Bank } & 2006.11 & BBVA Group (Spain) & $5.00 \%$ \\
\hline & & 2009.2 & BBVA Group & $10.07 \%$ \\
\hline 22 & $\begin{array}{c}\text { Shanghai Rural Commercial } \\
\text { Bank }\end{array}$ & 2006.11 & \begin{tabular}{|c|} 
Australia and New Zealand Banking \\
Group
\end{tabular} & $19.99 \%$ \\
\hline 23 & $\begin{array}{c}\text { Chongqing City Commercial } \\
\text { Bank }\end{array}$ & 2006.12 & Carlyle, Dah Sing Banking Group & $24.99 \%$ \\
\hline 24 & Bank of Qingdao & 2007.7 & Intesa Sanpaolo (Italy) & $19.99 \%$ \\
\hline 25 & Bank of Chengdu & 2007.11 & Hong Leong Bank (Malaysia) & $19.99 \%$ \\
\hline 26 & Xiamen Bank & 2008.12 & Fubon Bank (Hong Kong) & $19.99 \%$ \\
\hline
\end{tabular}

Sources: Bankscope, and Banks' official websites.

Some literature has argued that ownership could be endogenous as investors may be attracted by the banks' good performance (Gugler \& Weigland, 2003). However, Barry et al. (2011) show that the ownership endogeneity problem is not a major issue in their study. Liang et al. (2013) pointed out that many reforms that took place within a Chinese bank were guided and required by the regulatory authorities. This might be also the case for the change in ownership for most of the banks in our sample, which 
suggests that the endogeneity problem associated with the ownership variable is not very serious. Therefore, we first treat ownership as exogenous and use the traditional random and fixed effects models (static models). We then use the dynamic panel data estimation technique to address the potential endogeneity problem by using the lagged values of the ownership variable as instruments. The inclusion of a lagged dependent variable allows to capture the fact that a firm performance in the previous period may have a strong impact on its performance in the current period. Ignoring the past trend tends to overstate the effects of other variables. The system GMM approach, proposed by Arellano and Bover (1995) and Blundell and Bond (1998), is used for the dynamic panel data model.

An examination of the data suggests that the foreign bank branch variable has an upward trend and the COI shows a slight downward trend. Other performance variables do not exhibit an obvious trend. ${ }^{4}$ A spurious correlation could arise between two trending variables. Including a time trend could solve this problem. Wooldridge (2006) pointed out that even if only the independent variable grows over time and the dependent variable has no noticeable trend, including a trend in the regression can improve the precision of the model. Therefore, a time trend variable is included in all the models.

\section{Results and discussion}

\footnotetext{
${ }^{4}$ The trend patterns for these variables are not reported here for lack of space, but are available upon request.
} 
Table 2 reports the descriptive statistics for the financial performance measures and other variables. The average ROA and ROE for the Chinese banks for the period 19932002 reported in Fu and Heffernan (2009) were 0.9 per cent and 16.2 per cent, respectively. Our sample reports a mean of 0.75 per cent for ROA and an average ROE of 13.9 per cent for the $2002-11$ period. Compared to the means of the five dependent variables, the values of their standard deviation are relatively large, indicating that the performance variables vary significantly across banks and over years.

Table 2: Descriptive statistics.

\begin{tabular}{|c|c|c|c|c|c|c|c|}
\hline & $\begin{array}{l}\text { ROA } \\
(\%)\end{array}$ & $\begin{array}{l}\text { ROE } \\
(\%)\end{array}$ & $\begin{array}{l}\text { TCR1 } \\
(\%)\end{array}$ & $\begin{array}{l}\text { TCR } \\
(\%)\end{array}$ & $\begin{array}{l}\text { COI } \\
(\%)\end{array}$ & $\begin{array}{l}\text { Foreign } \\
\text { investment } \\
(\%)\end{array}$ & $\begin{array}{l}\text { Total assets } \\
\text { (RMB } \\
\text { million) }\end{array}$ \\
\hline \multicolumn{8}{|c|}{ All banks } \\
\hline Obs. & 317 & 319 & 242 & 270 & 324 & 390 & 328 \\
\hline mean & 0.75 & 13.90 & 9.05 & 10.89 & 44.74 & 7.09 & 1145909 \\
\hline $\begin{array}{l}\text { Std. } \\
\text { Dev. }\end{array}$ & 0.48 & 16.12 & 4.82 & 4.86 & 15.37 & 9.30 & 2479854 \\
\hline Min. & -1.39 & -193.9 & -1.50 & -1.50 & 23.49 & 0 & 5121 \\
\hline Max. & 3 & 83.46 & 62.60 & 62.60 & 169.87 & 25 & 15500000 \\
\hline \multicolumn{8}{|c|}{ Banks with foreign equity } \\
\hline Obs. & 146 & 146 & 146 & 151 & 154 & 166 & 155 \\
\hline mean & 0.85 & 14.10 & 9.49 & 11.49 & 38.99 & 16.67 & 1740833 \\
\hline $\begin{array}{l}\text { Std. } \\
\text { Dev. }\end{array}$ & 0.44 & 20.42 & 5.68 & 5.59 & 12.95 & 6.58 & 3096166 \\
\hline Min. & -1.39 & -193.90 & -1.50 & -1.50 & 23.49 & 3.30 & 15338 \\
\hline Max. & 2.23 & 41.13 & 62.60 & 62.60 & 169.87 & 25 & 15500000 \\
\hline \multicolumn{8}{|c|}{ Banks without foreign equity } \\
\hline Obs. & 171 & 173 & 96 & 119 & 170 & & 173 \\
\hline mean & 0.66 & 13.74 & 8.39 & 10.14 & 48.87 & & 612884 \\
\hline $\begin{array}{l}\text { Std. } \\
\text { Dev. }\end{array}$ & 0.5 & 11.36 & 3.02 & 3.62 & 15.92 & & 1582335 \\
\hline Min. & -0.97 & -23.55 & 0.75 & 1.45 & 25.10 & & 5121 \\
\hline Max. & 3 & 83.46 & 16.35 & 24.30 & 95 & & 10000000 \\
\hline
\end{tabular}




\begin{tabular}{|l|l|l|l|l|l|l|l|}
\hline \multicolumn{7}{|l|}{ Publicly listed banks } \\
\hline Obs. & 75 & 75 & 80 & 82 & 82 & 90 & 82 \\
\hline mean & 0.95 & 17.66 & 9.14 & 11.80 & 37.45 & 10.82 & 3067983 \\
\hline $\begin{array}{l}\text { Std. } \\
\text { Dev. }\end{array}$ & 0.36 & 5.26 & 3.21 & 3.22 & 6.05 & 8.42 & 3862036 \\
\hline Min. & 0.14 & 4.18 & 2.30 & 2.30 & 23.49 & 0 & 75511 \\
\hline Max. & 1.58 & 31.17 & 20.70 & 24.10 & 57.03 & 24.90 & 15500000 \\
\hline
\end{tabular}

The pair-wise correlations among independent variables were calculated to check if there exists potential multicollinearity problem. High pair-wise correlations among regressors, say, in excess of 0.8 , may indicate a multicollinearity problem (Gujarati, 2003). An examination of the correlation matrix does not suggest the presence of multicollinearity, as most of the bivariate correlations are not more than 0.5 with the highest being only 0.67 . However, it should be noted that this is a sufficient but not a necessary condition, because sometimes even if the pair-wise correlations among regressors are low, a multicollinearity problem may still exist. Therefore, a collinearity diagnostic test was subsequently conducted on all the independent variables as an additional test for the presence of multicollinearity. A variance-inflating factor (VIF)) can be used to detect multicollinearity. A rule of thumb states that a value of VIF of an independent variable greater than 10 indicates possible collinearity between this variable with other regressors (Gujarati, 2003). Again, no serious multicollinearity problem has been found. The results of the tests can be provided upon request.

For the static model, a Hausman test can be used to see whether the random effects model or the fixed effects model is preferred. The Hausman test compares the differences of the fixed and random effects with the null hypothesis that the coefficients 
estimated by the efficient random effects estimator are the same as the ones estimated by the consistent fixed effects estimator. The random effects model makes full use of the information provided by cross-sectional and time series data, and is thus more efficient if the explanatory variables are not correlated with the unobserved effects. If the Hausman test prefers a fixed effects model, we also report the results of the random model in Tables 3 and 4. To accommodate the potential serial correlation and heteroskedasticity problem, robust standard errors are reported. The results of the dynamic models were reported in Table 5. The lagged ROE of a previous period has no significant effect and so the results for the performance indicator ROE are not reported in Table 5.

The results from the static and dynamic models are largely consistent. Foreign ownership participation, regardless of being measured by the foreign ownership dummy, the long run dummy or by the percentage of foreign investment, is not significantly and positively associated with the ROA or the ROE at the 5 per cent level. Instead, the coefficient of the long run dummy in Table 3 shows that three years after the introduction of foreign strategic partners, the ROA was significantly lower at the 5 per cent level after other factors were controlled for. In addition, the foreign ownership dummy has a negative impact on the ROE at the 10 per cent level as shown by the random effects model. These results generated from the data for 2002 to 2011 are consistent with the findings in Jiang et al. (2012) whose datasets cover the 1995-2008 period. They provide some explanations for this unexpected result. For example, banks may pursue long-term benefits at the cost of sacrificing short-term profitability. However, the negative coefficient of the long run dummy in this study may imply that 
the strategic partners had limited or no influence over the banks' operations in improving their long term profitability probably because of the 25 per cent upper limit on foreign ownership participation. It is also possible that, as minority owners, foreign investors do not have a strong incentive to introduce advanced technologies, new products and suitable corporate governance mechanisms to the domestic banks (Shen et al., 2009).

One intention of introducing foreign strategic investors is to increase the banks' capital adequacy ratio. Table 4 shows that the percentage of foreign investment has a positive impact on both TCR1 and TCR at the 10 per cent significance level. However, Table 3 suggests that in the long term, the TCR1 would be significantly lower for those banks that have had foreign ownership participation. We have not found any significant effects of the presence of foreign investment on COI, a measure for cost efficiency.

It is noteworthy that the number foreign bank branches has a consistent and significant impact on the performance measures with expected signs except for the TCR1 variable in Tables 3 and 4. The dynamic models also suggest that foreign bank entry in this form is positively associated with ROA and TCR. It appears that the direct competition of foreign banks has made Chinese banks more profitable and more cost efficient. This finding has important implication as it supports the policy of opening the banking sector to foreign banks, which might lead to Chinese banks becoming more competitive. Although it has been argued that introducing foreign capital to Chinese banks would improve corporate management structures and bring in new technologies, products and management skills, it appears that foreign bank entry in the form of establishing 
branches would be a more powerful force for the domestic banks to change than minority ownership participation. In fact, in today's global and information era, it is not difficult to adopt new technologies and to recruit people with high management skills. The physical presence of foreign banks in China changes the market structure, which could be more effective in driving their Chinese counterparts to be innovative and to adopt new technologies and skills. This is consistent with the structure-conductperformance paradigm which suggests that the structure of a market influences the conduct of the firms that operate in it, and in turn this conduct influences the performance of those firms. This paradigm shows that market structure can be altered in order to achieve a desired outcome with improved conduct and performance (Sosnick, 1958).

It can be seen from Tables 3 and 4 that the banks that have gone public have significantly better TCR1 at the 1 per cent significance level. Not surprisingly, better macroeconomic conditions measured by the GDP growth rate could help the banks to improve the COI. Higher inflation rates have similar effects as shown in Tables 3-5. Tables 4 and 5 indicate that the SCBs had significantly higher TCR 1 and TCR, which may partly demonstrate the success of the series of reforms implemented on the Big Four in the past decades. 


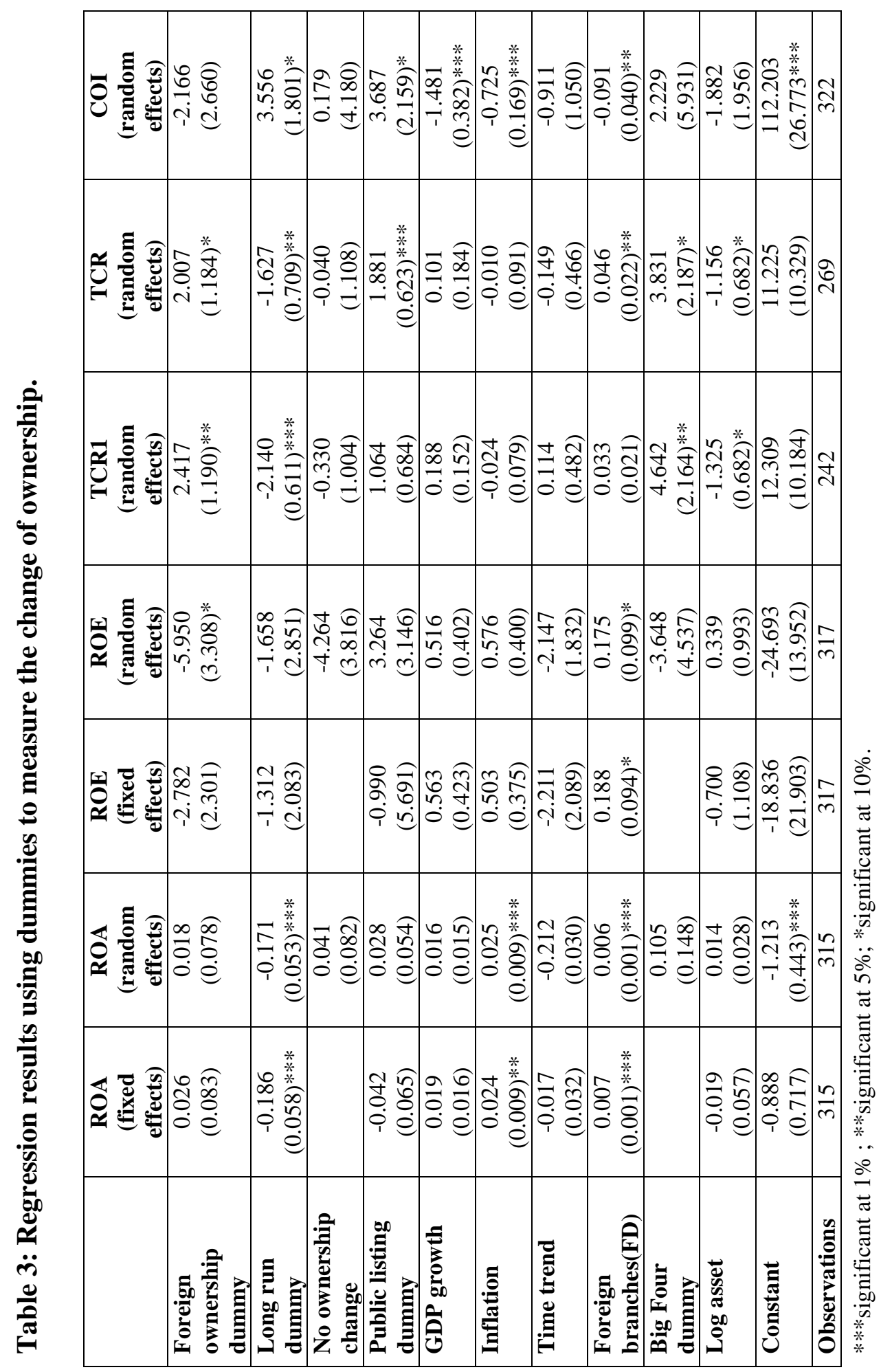


$\bar{\lambda}$

\begin{tabular}{|c|c|c|c|c|c|c|c|c|c|c|c|}
\hline ○一 & 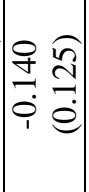 & 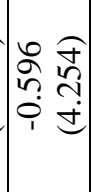 & 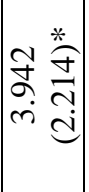 & 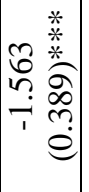 & 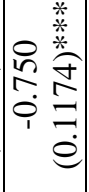 & 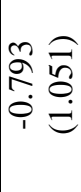 & 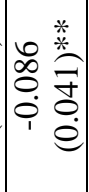 & 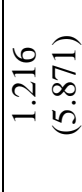 & 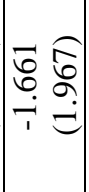 & 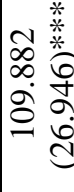 & 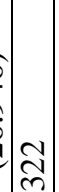 \\
\hline ర0 & \begin{tabular}{cc}
0 & 0 \\
\pm & 0 \\
\hdashline & 0 \\
& 0 \\
\end{tabular} & & 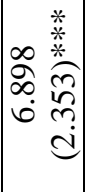 & 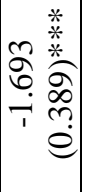 & 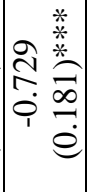 & & 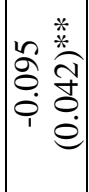 & & 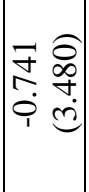 & 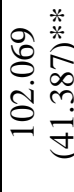 & त̂ \\
\hline 䒕 & $\begin{array}{cc}0 & \widehat{n} \\
\infty & \tilde{n} \\
0 & 0 \\
0 & 0 \\
0\end{array}$ & 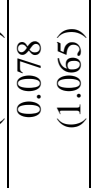 & 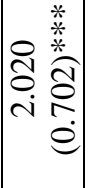 & 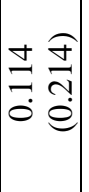 & $\begin{array}{ll}1 & 0 \\
0 & 0 \\
0 & 0 \\
0 & 0 \\
0\end{array}$ & & 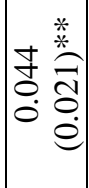 & 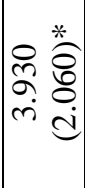 & 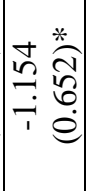 & 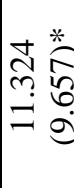 & ì \\
\hline 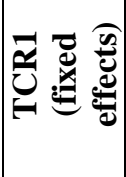 & 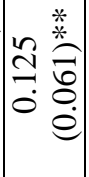 & & 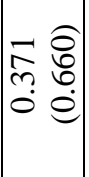 & 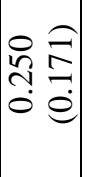 & $\mid \begin{array}{cc}0 & \widehat{f} \\
0 & 0 \\
0 & 0 \\
0 & 0 \\
1\end{array}$ & & 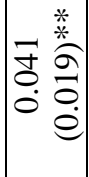 & & 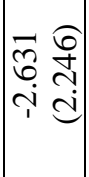 & 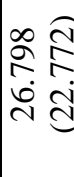 & $\frac{\text { ป }}{\mathcal{N}}$ \\
\hline 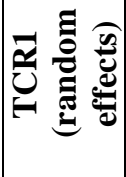 & 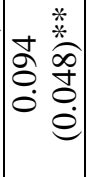 & 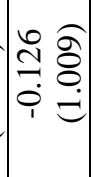 & 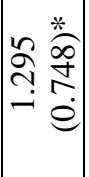 & 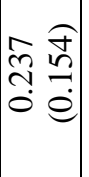 & $\mid \begin{array}{ll}0 & \widehat{a} \\
0 & 0 \\
0 & 0 \\
0 & 0 \\
1 & 0\end{array}$ & 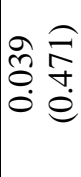 & 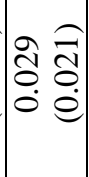 & 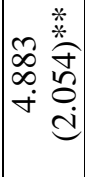 & 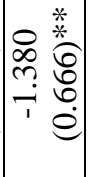 & 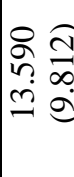 & $\sqrt[4]{\frac{4}{2}}$ \\
\hline 될 & 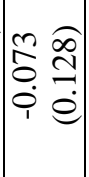 & 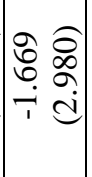 & 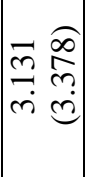 & 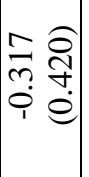 & $\begin{array}{cc}\infty & \widehat{9} \\
0 & \stackrel{9}{y} \\
0 & 0 \\
0\end{array}$ & 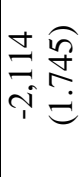 & $\mid$\begin{tabular}{cc|c}
0 & $*$ \\
0 & 0 & 0 \\
0 & 0 & 0 \\
0
\end{tabular} & 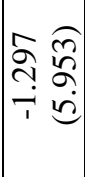 & $\begin{array}{cc} & 0 \\
0 & 8 \\
0 & + \\
0 & \vdots \\
1 & =\end{array}$ & 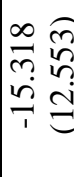 & $\frac{\bar{n}}{m}$ \\
\hline 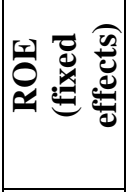 & 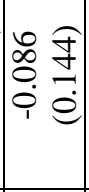 & & 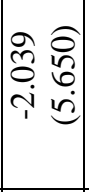 & 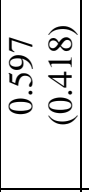 & 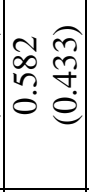 & 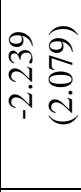 & 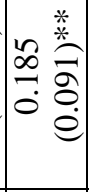 & & 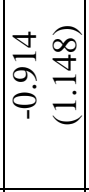 & 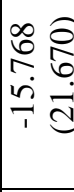 & $\frac{\bar{n}}{n}$ \\
\hline 死 & 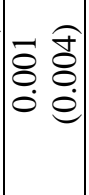 & $\mid \begin{array}{cc}\vec{b} & \widehat{0} \\
0 & 0 \\
0 & \stackrel{0}{9}\end{array}$ & 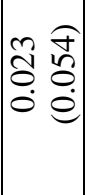 & 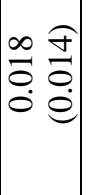 & 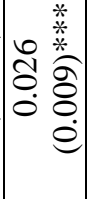 & 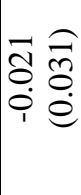 & 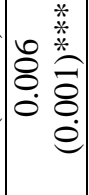 & 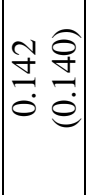 & 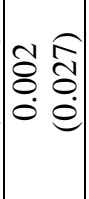 & 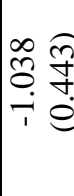 & $\frac{n}{m}$ \\
\hline 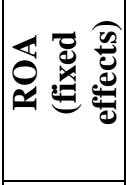 & $\begin{array}{ll}-\overline{0} & \tilde{8} \\
8 & 8 \\
0 & 0 \\
0\end{array}$ & & $\mid \begin{array}{ll}\infty & 0 \\
0 & 0 \\
0 & 0 \\
0 & 0 \\
1 & 0\end{array}$ & 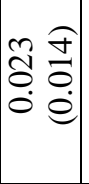 & 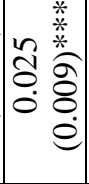 & $\begin{array}{ll}1 & \widehat{a} \\
0 & 0 \\
0 & 0 \\
0 & 0\end{array}$ & 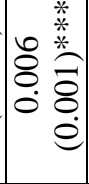 & & $\begin{array}{ll}n & \widehat{\hat{\sigma}} \\
\hat{0} & 0 \\
0 & 0 \\
1 & 0 \\
\end{array}$ & 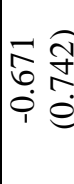 & $\frac{n}{n}$ \\
\hline & 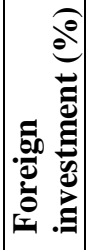 & 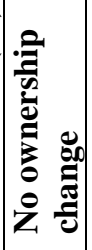 & 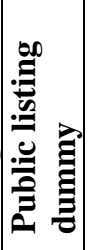 & 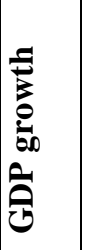 & $\mid$ & 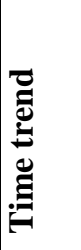 & 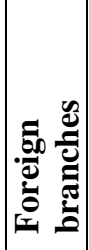 & 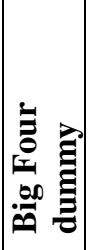 & $\begin{array}{l}0 \\
0 \\
0 \\
0 \\
0 \\
00 \\
0 \\
0\end{array}$ & 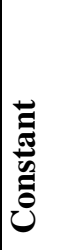 & 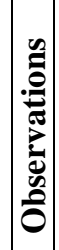 \\
\hline
\end{tabular}


สี

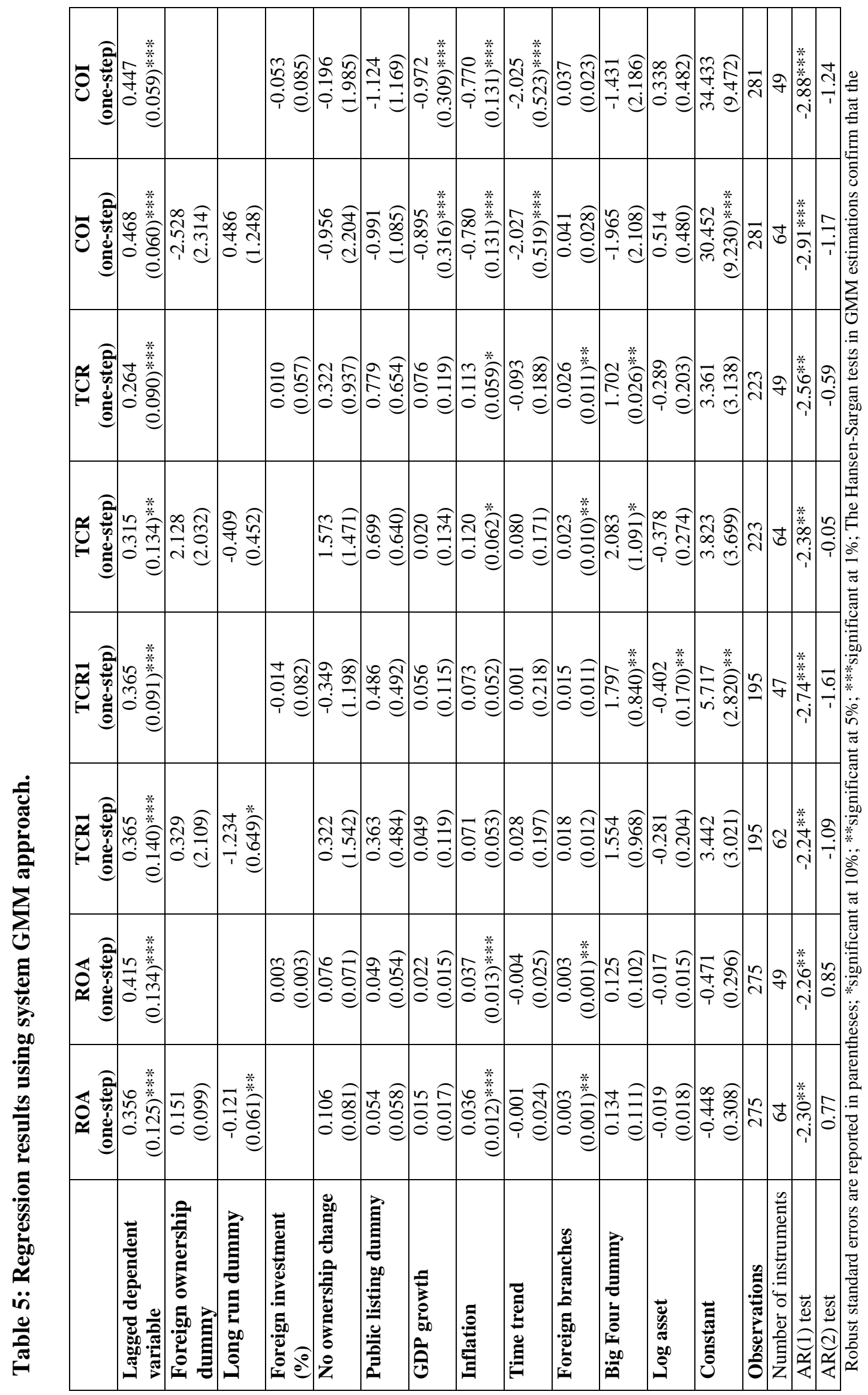




\section{Conclusion and policy implication}

Since the early 2000s, China has encouraged its domestic banks to introduce foreign investment in a bid to build a more stable and stronger banking system. Consequently, more than 30 Chinese banks have invited foreign strategic investors, most of whom are world leading banks. In the meantime, China has gradually fulfilled its WTO accession commitment to open its domestic market to foreign banks. This research has examined the effects of the two modes of foreign bank entry, namely, minority ownership participation and setting up branches and subsidiaries, on the performance of Chinese banks. Our results show that although foreign banks are concentrated in a few capital cities with relatively small market share, their impact on the domestic banking performance is significant and encouraging. The increasing number of foreign banks in China is positively associated with higher ROA, ROE, and TCR, and negatively related to COI for domestic banks, suggesting that the presence of foreign banks could be a significant driver for domestic banks to improve profitability and efficiency. Opening the country to foreign banks has made Chinese banks stronger. This sends a strong message to the policy makers that Chinese banks could benefit from the entry of foreign banks, and that creating entry barriers and operational restrictions to protect domestic banks is unnecessary.

However, our results suggest that there is no symmetrically significant impact of the minority ownership participation on the performance indicators of Chinese banks. Instead, in the long term, the banks that have introduced foreign investment could have lower ROA and TCR1. It is highly possible that minority ownership participation does not give the strategic partners a strong incentive to bring in advanced technologies, skills and new products. Policy makers could consider relaxing foreign ownership restrictions. At the least, this research shows that a higher percentage of foreign investment has a positive effect on capital adequacy ratios for banks in China. 


\section{References:}

Arellano, M., and O. Bover, (1995) Another look at the instrumental variables estimation of error components models, Journal of Econometrics, 68, pp.29-51.

Barry, T.A., L. Lepetit, and A. Tarazi, (2011) Ownership structure and risk in publicly held and privately owned banks. Journal of Banking \& Finance, 35(5) pp.1327-1340.

Berger, A.N., I. Hasan and M. Zhou (2009) Bank ownership and efficiency in China: What will happen in the world's largest nation? Journal of Banking \& Finance, 33(1) pp. 113-30.

Berger, A., Clarke, G.R.G. Cull, R. Klapper, L. and G.F., Udell (2005) Corporate governance and bank performance: A joint analysis of the static, selection, and dynamic effects of domestic, foreign, and state ownership, Journal of Banking \& Finance, 29(8/9) pp. 2179-221.

Blundell, R., and S. Bond (1998) Initial conditions and moment restrictions in dynamic panel data models. Journal of Econometrics, 87, pp.115-143.

Bonin, J.P., I. Hasan, and P., Wachtel (2005) Bank performance, efficiency and ownership in transition countries, Journal of Banking \& Finance, 29(1) pp. 31-53.

Bonin, J.P., K. Mizsei, I. P. Szekely, and P., Wachtel (1998). Banking in transition economies: Developing market oriented banking sectors in Eastern Europe. Edward Elgar Publishing Limited, Cheltenham, UK.

Chen, C.H., C. C. Mai, Y. L. Liu, and S. Y. Mai (2009) Privatisation and optimal share release in the Chinese banking industry, Economic Modelling, 26(6) pp. 1611-71.

Claessens, S., A. Demirguc-Kunt, and H. Huizinga (2001) How Does Foreign Entry Affect Domestic Banking Markets? Journal of Banking \& Finance, 25(5) pp. 891-911.

Denizer, C., (2000) Foreign bank entry in Turkey's banking sector, 1980-1997 in S. Claessens, and M. Jansen, ed.: The Internationalization of Financial Services: Issues and Lessons for Developing Countries. Kluwer Academic Press, Dordrecht and Boston. 
De Haas, R., and I. Van Lelyveld (2010) Internal capital markets and lending by multinational bank subsidiaries, Journal of Financial Intermediation, 19(1) pp. 689-721

De Haas, R., Y. Korniyenko, E. Loukoianova, and A. Pivovarsk (2011) Foreign Banks during the Crisis: Sinners or Saints? Mimeo, European Bank for Reconstruction and Development.

Fu, X., and S. A. Heffernan (2009) The effects of reform on China's bank structure and performance, Journal of Banking \& Finance, 33(1), pp. 39-52.

Gugler, K., and J. Weigland, (2003) Is ownership really endogenous? Applied Economic Letters, 10, pp. 483-486.

Gujarati, D.N. (2003) Basic Econometrics, 4th Ed., McGraw-Hill/Irwin, New York.

Hasan, I., and R. Xie (2012) A note on foreign bank entry and bank corporate governance in China. BOFIT Discussion Papers, Bank of Finland.

He, L., and X. Fan, 2004, Foreign banks in post-WTO China: An intermediate assessment, China and World Economy, 12(5) pp. 3-16.

Hope, N.C., J. Laurenceson, and F. Qin, 2008, The impact of direct investment by foreign banks on China's banking industry, Stanford Centre for International Development Working Paper No. 362. Stanford University.

Jiang, C., G. Feng, and J. Zhang, 2012, Corporate governance and bank performance in China, Journal of Chinese Economic and Business Studies, 10(2) pp. 131-46.

Lensink, R., and N. Hermes, 2004, The short-term effects of foreign bank entry on domestic bank behaviour: Does economic development matter? Journal of Banking \& Finance, 28(3) pp. 553-68. Lin, X., and Y. Zhang (2009) Bank ownership reform and bank performance in China, Journal of Banking \& Finance, 33(1) pp. 1000-010.

Martin, S., and D. Parker (1997) The Impact of Privatisation. Routledge, London. 
Mathieson, D., and J. Roldos (2001) The role of foreign banks in emerging markets. The World Bank, International Monetary Fund and Brookings Institution $3^{\text {rd }}$ Annual Financial Markets and Development Conference, New York, April 19-21, 2001.

Shen, C.H., C. H. Lu, and M. W. Wu (2009) Impact of foreign bank entry on the performance of Chinese banks, China \& World Economy. 17(3) pp. 102-21.

Sosnick, S.H. (1958), A critique of concepts of workable competition, Quarterly Journal of Economics. 72(3) pp. 380-423.

Williams, J., and N. Nguyen (2005) Financial liberalisation, crisis, and restructuring: A comparative study of bank performance and bank governance in South East Asia, Journal of Banking \& Finance, 29(8/9) pp. 2119-54.

Wooldridge, J. M. (2006) Introductory Econometrics: A Modern Approach, 3rd ed. Mason, OH: Thomson/South-Western.

$\mathrm{Xu}, \mathrm{Y} .(2011)$ Towards a more accurate measure of foreign bank entry and its impact on domestic banking performance: The case of China, Journal of Banking \& Finance, 35(4) pp. 886-901. Yao, S., Z. Han, and G. Feng (2008) Ownership reform, foreign competition and efficiency of Chinese commercial banks: A non-parametric approach, The World Economy, 31(10) pp. 1310-21. 